\title{
HATÁRON ÁTNYÚLÓ INGÁZÁS, MUNKAVÁLLALÁS AZ OSZTRÁK-MAGYAR HATÁRTÉRSÉGBEN
}

\author{
(Transborder Commuting, Employment on the Austrian- \\ Hungarian Border Region)
}

\section{HARDI TAMÁS}

Kulcsszavak:

ingázás munkaügy külföldi munkavállalás határon átnyúló együttmüködés

Az osztrák-magyar határ mentén élök számára fontos lehetôség, hogy a szomszédban. Ausztriában a hazainál lényegesen magasabb bérért vállalhatnak munkát, s ezért még el sem kell költözniük, hanem akâr napi ingázással järhatnak be munkahelyükre. Emellett az itthon dolgozók számára jó kereset kiegészítést jelenthet az idöszakonkénti munkavállalás. Jelen tanulmány interjúk alapján bemutatja a rendszerváltás utáni idốszak határon átnyúló munkaügyi együttmüködéseinek kialakulását, majd egy lakossági, valamint egy speciális munkavállalói kérdöív segítségével kíséreli meg bemutatni az Ausztriában dolgozó magyar legális és illegális munkavállalók csoportját, megbecsülni létszámukat, körüulírni jellemzöiket, motivációikat, nehézségeiket.

\section{Bevezetés}

Az osztrák-magyar határtérség egyik leginkább egyedülálló jelensége a munkavállalás lehetősége a határ másik oldalán. Tỏbbi határszakaszunkon a szomszédos határtérségek maguk is munkanélküliségi problémákkal küzdenek, illetve a szomszédban elérhetó bér nem buzdítja a magyarországi munkavállalókat arra, hogy a másik országban helyezkedjenek el. Ezzel szemben Burgenland, Ausztria a rendszerváltás óta csábítja a magyarokat, így a legális és illegális ingázás az egyik legtipikusabb jelenséggé vált a térségben.

Ez a munkavállalás már korán félelmeket ébresztett a szomszéd térség lakóiban, a határok könnyebb átlépése kapcsán az osztrák munkaerópiacra „rászabaduló” magyar munkavállalók hadaival riogatták sokan a közvéleményt Ausztriában. Kétségtelen tény, hogy a rendszerváltás után jelentősen megnőtt az átjáró dolgozók száma, s az illegális munkavállalás is nagyszámú volt, különösen a mezögazdasági idénymunkások, az építőipar stb. területén. Osztrák oldalon a munkaügyi ellenórzések alkalmával gyakran találtak olyan vállalkozást, amely engedély nélkül alkalmazott magyar munkavállalót (Rechnitzer 2005). A kilencvenes évek végén a naponta átjárók számát mintegy 10-15 ezer fó közé becsuiltük.

Elöljáróban elmondhatjuk, hogy az EU-csatlakozás után, a határok elválasztó szerepének csökkenésével megindul a természetes, funkcionális kapcsolatokkal rendelkező határon átnyúló (integrált) régiók kialakulása, amelyek társadalma és gazdasága az eltérổ gazdasági rendszerekből származó helyzeti előnyöket a saját javára 
Hardi Tamás: Határon átnyúló ingázás, munkavállalás az osztrák-magyar határtérségben.

tudja fordítani. Magyarország határai mentén erre a legnagyobb esély itt, ezen a határszakaszon van, azon belül is az északi rész az (beleértve a szlovák határtérséget is), amely a közeli centrumtérségek és a gazdasági dinamika miatt már elindult ezen az úton (Hardi 2004).

\section{Munkaügyi együttmüködések a határon át}

Az illegális munkavállalás ténye már korán munkaügyi együttmüködésekre ösztönözte a határ két oldalán érintett szerveket. Így közös munkaügyi stratégiát dolgoztak ki, s a határ menti térségek ingázásáról külön keretegyezmény rendelkezett (Rechnitzer 1999; Csapó 1999).

Ha a munkavállalás történetét nézzük, látható, hogy a határtérség települései között hagyományos a munkaeröcsere. Ez természetes volt, különösen, amikor még nem választotta el államhatár e településeket egymástól. A határ megvonása után is sokáig kétoldalú államközi egyezmények biztosították a gazdaság müködtetéséhez szükséges átjárási lehetőséget (Sallai 2003).

A kapcsolatok a határ két oldalán a munkaügyi szervezet megalakulásától, de még azt megelőzően is megvoltak Burgenlanddal. Elsősorban a kamarák szervezték az első ilyen jellegü együttmüködéseket. 1991-töl kezdődöen folyamatosan fejlesztették ki a munkaügyi központok a szakmai kapcsolatokat. Elöször a hozzájuk közelebb lévő hivatalokkal, kirendeltségekkel, majd a tartományi központokkal is. Az első időszakban ez inkább a magyar részről megnyilvánuló tapasztalatcserelátogatásokat jelentette részben Burgenlandban, részben Ausztria más területein. 1993 végén létrejött egy kétnapos találkozó Grazban a két ország munkaügyi szervezeteinek felső vezetöi között. A Határ menti Regionális Tanács, majd a West/Nyugat-Pannónia Eurégió keretében megvalósult az intézményes együttmüködés is. A Regionális Tanácsban Vas megye adta az elnöki tisztséget, sőt az elnök a Vas Megyei Munkaügyi Központ vezetöje volt, így messzemenően biztosítva volt a téma képviselete az együttmúködésben. A körvonalakat ezek az első együttmüködések adták. Később egyre több lett a kölcsönös látogatás, a megbeszélés, a tevékenység egyeztetése, mint pl. az oberwarti vásáron az osztrák munkaügyi szervek részvétele mintául szolgált ahhoz, hogy a Munkaügyi Központ részt vegyen a Szombathelyi Nemzetközi Vásáron. Másik hasznos példa az oberwarti és salzburgi pályaválasztási vásárok mintájára 1998-tól Szombathelyen, majd a következő évtől az ország más városaiban is megszervezésre kerültek. A Phare CBC programok indulásától (1995) részt vett a Munkaügyi Központ a magyar oldal Phare pályázatainak kivitelezésében. Összesen négy Phare projektet bonyolított le a munkaügyi szervezet. Témájuk: munkaerö-piaci képzéseket, valamint szociálökonómiai menedzserek, illetve pályaorientációs trénerek képzését jelentette. Ezeknek a programoknak a határon átnyúló jelleget az adta, hogy a képzésben szerepelt az Ausztriában folytatott tapasztalatcsere, látogatás. Másrészt közös, Interreg és Phare finanszírozású volt a pályaorientációs trénerképzés, mivel az ilyen szakemberekböl Burgenlandban éppúgy hiány mutatkozott, mint Magyarországon. Így müködött egy oberwarti és 
Hardi Tamás: Határon átnyúló ingázás, munkavállalás az osztrák-magyar határtérségben. Tér és Társadalom, 19. 2005. 2. 65-81. p.

TÉT XIX. évf. 2005 『 2

Határon átnyúló ingázás ...

67

egy szombathelyi csoport. A képzések között szerepel pl. a termálturizmus számára szakemberek képzése. Látszólag az osztrák és a magyar gyógyfürdők versenyben állnak egymással, azonban vannak olyan szegmensek, amelyben együtt tudnak müködni. Ilyen a kölcsönös képzés, pl. a wellness-szakemberek képzése, ami Ausztriában megoldott, de Magyarországon nem. A hazai szakemberek jelentős részének nincs meg a végzettsége, így nem vállalhat teljes felelösséget a munkájáért. Ebben az esetben munkaügyes kapcsolatrendszer segítségével ültek össze a turisztikai szektor képviselői, s valósítottak meg egy határon átnyúló párbeszédet. Fontos Phare támogatású program volt, hogy elkészítették a határ menti régió munkaerő-piaci stratégiáját is (Nyugat-Magyarország és ... 1998). 1995-től évente kerül megszervezésre az osztrák-magyar munkaủgyi konferencia. A konferencia finanszírozása közös. A konferenciák témái három fö csoportba sorolhatók:

- a civil társadalom (harmadik szektor) bevonása a munkaerỏ-piaci politika területére;

- az uniós tapasztalatok, projektek, technikák átvétele;

- a hátrányos helyzetü rétegek kezelése.

Fontos fejlódési pont az Unió munkaerö-közvetítési rendszeréhez (EURES) történỏ kapcsolódás. Müködik már egy olyan honlap, ahova feljelentkezhet az ügyfél, s már több esetben találtak ezen az úton ausztriai munkaadók magyar munkavállalóra.

\section{Az ingázó munkavállalás}

Ausztriában kétféle munkavállalási lehetőség van. 1997 óta létezik az ingázó munkavállalási lehetőség, amelynek keretében a két állam szervei által meghatározott létszám a három határ menti megyéböl vállalhat munkát Burgenlandban. A jogosultsághoz egy évi állandó vagy ideiglenes Győr-Moson-Sopron, Vas vagy Zala megyei lakcímmel kell rendelkezni. Szakmai megkötések vannak, nem lehet, pl. építőipari szakmákban, pedagógusként munkát vállalni ebben a keretben. A munkavállalás korlátlan ideig meghosszabbítható. A másik lehetőség a gyakornoki munkavállalás, ez az egész országra vonatkozik, Ausztriában Burgenland kivételével valamennyi tartományban vállalhat munkát a magyar állampolgár. Elsősorban a szakma és a nyelv gyakorlását teszi lehetővé ez a konstrukció.

Kezdetekben az ügyintézés még meglehetősen nehézkes volt. A szükséges dokumentumokat személyesen vitték át a határon Eisenstadtba a Munkaügyi Központ dolgozói. Mára már kiépült az informatikai kapcsolat. Müködnek olyan számítógépes programok, amelyek segítségével az osztrák és magyar ügyintézők kölcsönösen látják, hogy pontosan hol áll egy-egy konkrét ügy, az osztrák fél pedig látja az ausztriai munkára jelentkezőket, $\mathrm{s}$ adott esetben ki is kérhetnek egy-egy munkavállalót külön, nem csak a jelentkezés sorrendjében.

A keretet 2003-ban 1700 före bỏvítették. A keretből nagyobb hányadot vesz igénybe Győr-Moson-Sopron megye, mivel a határtérség északi részén (Mosonmagyaróvár és a Fertő-tó térsége) tradicionálisabb a külföldi munkavállalás, kialakultabbak a családi kapcsolatok is, s Burgenland északi része gazdaságilag fejlettebb 
Hardi Tamás: Határon átnyúló ingázás, munkavállalás az osztrák-magyar határtérségben.

Tér és Társadalom, 19. 2005. 2. 65-81. p.

is a középső vagy déli résznél. Mezőgazdasága mindig is fejlett volt, Bécs éléskamrájának minősült. Zala megye, bár jogosult arra, hogy igénybe vegye a keretet, legfeljebb 10\%-át tudja kihasználni. A megye földrajzi adottságainál fogva egyszerủen nehezen valósítható meg a napi ingázás, illetve kicsi az osztrák határhoz közeli területe, ráadásul jelentősebb központ nélkül, ahonnan praktikusan érdemes még kijárni Burgenlandba munkát végezni.

A külföldi munkavállalást Ausztriában nagy mértékben befolyásolja, hogy szektoronként eltérőek a minimálbérek. A vendéglátásban, mezőgazdaságban alacsonyabbak, mint a szolgáltatásban, így az alacsonyabb bérrel rendelkező ágazatok az osztrák munkavállalók szempontjából kevésbé vonzók, ide nyilván beengedhető a külfö̈ldi munkaerő. Éppen ezért a várható migrációs folyamatok kimutatása érdekében érdemes lenne egy összehasonlító vizsgálatot végezni a különböző szakmákban tapasztalható bérkülönbségekről, mivel egyes területeken vélhetöen ez már nem annyira jelentős Nyugat-Magyarország és Burgenland között, mint az általánosan kimutatható jövedelmi különbség. Így pl. már ma is kimutatható, hogy hiány mutatkozik a diplomás ápolók körében. Ennek a hiánynak azonban nem annyira a burgenlandi munkavállalás az oka, hanem a távolabbi, jobban fizetỏ országok (pl. Olaszország) vonzó hatása. Burgenland szívja el viszont a jobban fizetett, magyar költségen kiképzett hegesztőket, vasas szakmájú szakmunkásokat. (A vasas szakterületen már ma is sok jugoszláv, horvát vendégmunkás dolgozik a magyar határtérségben.)

A magyar határtérségben szintén jelentös a külföldi munkavállalók száma. Mint az előbb említettük, több esetben pont a magyarok ingázó munkavállalása miatt alakulnak ki hiányszakmák. A munkaügy stratégiája ebben a tekintetben az, hogy csak oda enged be külföldi munkavállalót, ahol szük keresztmetszetek alakulnak ki, vagyis igyekszik azt elkerülni, hogy a beáramló külföldi munkaerő egy elavult, az olcsó munkabéren alapuló gazdasági szerkezetet konzerváljon.

Osztrák viszonylatban az ingázó munkavállalás kapcsán - természetesen - Magyarország is vállalta viszonossági alapon az azonos számú osztrák ingázó fogadását. Nyilvánvaló, hogy ez az oldal kisebb sikert aratott, mint a magyarok ausztriai munkavállalása. Azonban ez az irány sem teljesen értelmetlen. Osztrák oldalon ötletként már felmerült a munkaügyi szervek részéről, hogy az egyes szakmák bérkülönbségeinek pontos megismerése után lehetővé tennék az ausztriai munkavállalók magyarországi munkavállalását - hiányszakmákban - oly módon, hogy a két ország közötti bérkülönbséget osztrák oldalon megtérítenék a Nyugat-Magyarországon dolgozó osztrákoknak. Ez az eszköz egyelöre még nem került kifejlesztésre. 2003-ban Vas megyében a 449 külföldi munkavállalóból 59 osztrák, míg Győr-MosonSopron megyében az 1620 főből 35 fö érkezett Ausztriából.

Jelenleg Ausztriából zömében a vállalkozások tulajdonosai és a menedzser réteg (pl. Szentgotthárdi Ipari Park) jár át Magyarországra dolgozni. Ebben az esetben természetesen ezeknek az embereknek a bérezése Ausztriában történik. Jellemzö, hogy több külföldi tulajdonú vállalat menedzser rétege inkább Ausztriában él, s onnan naponta jár át a magyarországi telephelyre, mintsem Magyarországra költözzön, mivel a hazai életfeltételek nem megfelelőek a számára. 
Hardi Tamás: Határon átnyúló ingázás, munkavállalás az osztrák-magyar határtérségben. Tér és Társadalom, 19. 2005. 2. 65-81. p.

TÉT XIX. évf. 2005 - 2

Határon átnyúló ingázás ...

69

A fekete munkavállalás csökkenöben van. A sajtóban is egyre több információ lát napvilágot a fekete munkavállalásról, a kiszolgáltatottságról, másrészt a fekete munkáért jăró bér már kevésbé csábító napjainkban. Az osztrák szervek is egyre felkészültebbek. A várható szankciók miatt sem a munkaadónak, sem a munkavállalónak nem éri már meg annyira a kockázat vállalása. A nyári szezonban, a mezögazdasági munkákban, illetve a családi kapcsolatoknak köszönhetóen - lehet azt mondani - tradicionális a munkavállalás a magyar oldalról.

\section{A jövő}

$\mathrm{Az}$ osztrákok félelme a magyar munkaerőtöl még most is megvan. Azt is látni kell, hogy meglehetősen torz információk jutnak el az osztrák lakosság felé a magyar munkaerőpiacról. Így a munkaerő szabad áramlásával szemben megvalósítandó hét éves átmeneti időszak egyrészt megérthető, másrészt ezen torz információknak köszönhető. Másik oldalról viszont ez az átmeneti idöszak valamilyen formában a magyar határ menti térségek munkaeröpiacát is védi. Egy szabad munkaeröáramlás esetén ugyanis ezekben a térségekben jelentős munkaerő-hiány alakulhatna ki, különösen a diplomás, fiatal munkavállalók körében (pl. egészségügyi dolgozók), ha a nyugat-magyarországi értelmiség ingázó módon tudna vállalni munkát Ausztriában. Az osztrák félelmekben fontos azt is látni, hogy az ausztriai külföldi munkavállalók körében mintegy $11 \%$-ot tesznek ki a szomszédos országokból érkezők, a döntő hányad Európa más területéről vagy Európán kívülről származik.

A sok pozitív fejlemény ellenére az információáramlás nem teljes körü. Problémát okoz például, hogy az osztrák szervek nem adnak ki információt a magyar állampolgárok ausztriai munkavállalásáról, munkaviszonyáról. Így előfordulhat, hogy valaki Magyarországon munkanélküli segélyt vegyen fel, miközben Ausztriában legálisan, szerződéssel dolgozik, $s$ jövedelemhez jut. A magyar munkaügyi szervek ezt nem tudják megakadályozni, még akkor sem, ha nyilvánvaló az ausztriai munkavállalás ténye, mivel nincs a kezükben bizonyíték erról. Pedig a fekete gazdaság visszaszorítása okán ez mind a két fél érdekében állna.

A csatlakozás után járható út az ingázó keret folyamatos bővítése. Az Eurégió Foglalkoztatási Bizottságának ülésén felmerült osztrák részröl, hogy az ingázói munkavállalás jelentősége az átmeneti időszak alatt nőni fog. A hét év alatt fokozatosan bövítik a kereteket, esetleg az egyezmény területi hatálya is bỏvül, bár ez a konstrukció napi ingázásra készült. Ezzel ez a munkavállalási forma mintegy átvezeti a munkaeröpiacokat a szabad munkavállalás irányába.

\section{A határ mentén élók az osztrák munkahelyeken}

A határ menti megyékben felvett lakossági kérdőívünkben mintegy 1500 fơt kerestünk meg, s kérdéseink kőzött az ausztriai munkavállalásra vonatkozó információkat is kértiunk. (A kérdőív a lakosságra és a határtól való zónákra nézve reprezentatív volt. Erről részletesen lásd Csizmadia Zoltán tanulmányát [Csizmadia 2005].) 
Hardi Tamás: Határon átnyúló ingázás, munkavállalás az osztrák-magyar határtérségben.

Tér és Társadalom, 19. 2005. 2. 65-81. p.

70 Hardi Tamás

TÉT XIX. évf. 2005 『 2

Jelen értékelésnél tehát az egész lakosságra vonatkozó következtetéseket szeretnénk bemutatni.

Válaszadóink körében 6,5\% (97 fö) dolgozott már Ausztriában. Világosan látható az 1. táblázatból, hogy az ausztriai munkavállalás elsősorban a határ mentén élöket érinti, akik 30 kilométernél közelebb élnek az osztrák határhoz. Ott a népesség 10\%-a már végzett munkát a szomszédban. A távolabb élök már kisebb arányban vesznek részt az ingázásban.

\begin{tabular}{|c|c|c|c|c|}
\hline \multicolumn{5}{|c|}{$\begin{array}{c}\text { 1. TÁBLÁZAT } \\
\text { Vállalt-e már munkát Ausztriában? } \\
\text { (Have the Responsive Ever Worked in Austria?) }\end{array}$} \\
\hline & \multicolumn{3}{|c|}{ A lakóhely elhelyezkedése a határtól } & \multirow[b]{2}{*}{ Összesen } \\
\hline & $\begin{array}{c}30 \mathrm{~km}-\mathrm{en} \\
\text { belül }\end{array}$ & $30-60 \mathrm{~km}$ & $60 \mathrm{~km}-\mathrm{en} \mathrm{túl}$ & \\
\hline & \multicolumn{4}{|c|}{$\%$} \\
\hline $\begin{array}{l}\text { Dolgozott már } \\
\text { Ausztriában }\end{array}$ & 10,2 & 4,4 & 0,7 & 6,5 \\
\hline $\begin{array}{l}\text { Nem dolgozott } \\
\text { még Ausztriában }\end{array}$ & 89,8 & 95,6 & 99,3 & 93,5 \\
\hline
\end{tabular}

Forrás: Kérdőívek 2004.

Hozzá kell tennünk, hogy a megkérdezetteknek csupán 1,1\%-a (17 fö) mondta, hogy jelenleg is dolgozik a határ másik oldalán (egy fỏ kivételével valamennyien a határhoz legközelebbi sávban laknak), a többség csak korábban tette ezt, illetve megszakításokkal jár ki. (Felvételünk már az idénymunkák elmúltával készültt.)

Ha eredményeinket kivetítjük az egész népességre, akkor azt mondhatjuk, hogy a három határ menti megye népességéből mintegy 60-70 ezer ember járt már Ausztriában munkavállalóként a rendszerváltás óta, s napjainkban a leginkább érintett 30 kilométeres sávból 7-8 ezer fö, a három megyéböl mintegy 9 ezer fö jár át dolgozni (november hónapban, tehát nem az idénymunkák idején).

Azok között, akik dolgoztak már Ausztriában, a többség $(57,7 \%)$ engedély nélküil tette ezt, míg a többiek munkavállalási engedéllyel (2. táblázat). Az engedély meglétét a legutóbbi kintlét alkalma kapcsán kérdeztük, tehát azok, akik utoljára rendelkeztek engedéllyel, korábban dolgozhattak anélkül is. A másik, munkavállalói kérdöívünkben erre is keressük a választ.)

A kérdéseinkre adott válaszok szerint az ausztriai munkavállalás leginkább a fiatal felnőttekre, illetve az 50-59 éves korosztályra jellemzö, s inkább a férfiakra, mint a nőkre. Az illegális munkavállalás ezen belül elsősorban a fiatal felnőtt népességet (30-39 év) érinti. Ezzel egybecseng a bécsi Ost- und Südosteuropa Institut és az MTA RKK NYUTI által 1998-ban közösen végzett felmérés eredménye, melynek során a magyar és osztrák lakosok másik oldalról alkotott mentális képét vizsgáltuk. Ezek szerint a magyar oldalon élök közül a 30-50 éves korosztály volt az, amely számtalan lehetőség közül az osztrák oldal említésekor elsösorban a munkalehetöségekre asszociált, s a határ menti lét elönyeként nevezte meg azt (Nárai 1999). 
Hardi Tamás: Határon átnyúló ingázás, munkavállalás az osztrák-magyar határtérségben. Tér és Társadalom, 19. 2005. 2. 65-81. p.

TÉT XIX. évf. 2005 - 2

Határon átnyúló ingázás ... 71

\section{TÁBLÁZAT}

Az Ausztriában munkát vállalók megoszlása korra, nemre és a munkavállalás módjára való tekintettel

(Distribution of Emloyees in Austria According to Age, Sex and Type of Employement)

\begin{tabular}{|c|c|c|c|c|c|c|c|c|}
\hline \multirow{3}{*}{$\mathrm{Nem}$} & \multirow{3}{*}{$\begin{array}{l}\text { A munkaválla- } \\
\text { lás módja }\end{array}$} & \multicolumn{6}{|c|}{ Korcsoport (életév) } & \multirow[b]{2}{*}{ Összes } \\
\hline & & 60 & $\begin{array}{c}50- \\
59\end{array}$ & $\begin{array}{c}40- \\
49\end{array}$ & $\begin{array}{c}30- \\
39\end{array}$ & $\begin{array}{l}18- \\
29\end{array}$ & 17 & \\
\hline & & \multicolumn{7}{|c|}{$f_{o}^{\prime \prime}$} \\
\hline \multirow[t]{2}{*}{ Férfi } & Legális & 2 & 9 & 7 & 7 & 3 & 0 & 28 \\
\hline & Illegális & 6 & 9 & 4 & 12 & 9 & 0 & 40 \\
\hline \multirow[t]{2}{*}{ Nó } & Legális & 1 & 2 & 4 & 4 & 2 & 0 & 13 \\
\hline & Illegális & 2 & 4 & 3 & 4 & 3 & 0 & 16 \\
\hline Összese & & 11 & 24 & 18 & 27 & 17 & 0 & 97 \\
\hline
\end{tabular}

Forrás: Kérdőívek 2004.

A munkát vállalók végzettségét tekintve ugyanakkor nem találunk jelentős eltéréseket sem az illegálisan és engedéllyel munkát vállalók, sem pedig az ingázók és a teljes válaszadói kör csoportja között (3. táblázat).

3. TÁBLÁZAT

Az Ausztriában munkát vállalók és az összes megkérdezett végzettség szerinti megoszlása

(Distribution of Emloyees in Austria and all Responsives According to Qualification)

\begin{tabular}{|c|c|c|c|c|c|c|c|}
\hline \multirow{3}{*}{ Képzettség } & \multicolumn{6}{|c|}{ Az Ausztriában munkát vállalók közulil } & \multirow{2}{*}{$\begin{array}{c}\overline{A z} \\
\text { összes } \\
\text { válasz- } \\
\text { adó } \\
\text { közül }\end{array}$} \\
\hline & $\begin{array}{l}\text { Legá- } \\
\text { lis }\end{array}$ & $\begin{array}{l}\text { Ille- } \\
\text { gális }\end{array}$ & $\ddot{O ̈ s s z}_{\text {s }}$ & $\begin{array}{l}\text { Legáa- } \\
\text { lis }\end{array}$ & $\begin{array}{l}\text { Ille- } \\
\text { gális }\end{array}$ & Össz. & \\
\hline & & fó & & & $\%$ & & $\%$ \\
\hline $\begin{array}{l}\text { Kevesebb, mint } \\
8 \text { általános }\end{array}$ & & 1 & 1 & 0,0 & 1,8 & 1,0 & 1,8 \\
\hline 8 általános & 8 & 11 & 19 & 19,5 & 19,6 & 19,6 & 19,6 \\
\hline Szakmunkásképző & 19 & 24 & 43 & 46,3 & 42,9 & 44,3 & 42,9 \\
\hline Szakközépiskola & 6 & 7 & 13 & 14,6 & 12,5 & 13,4 & 12,5 \\
\hline Gimnázium & 3 & 7 & 10 & 7,3 & 12,5 & 10,3 & 12,5 \\
\hline $\begin{array}{l}\text { Föiskola vagy felsö- } \\
\text { fokú Technikum }\end{array}$ & 4 & 5 & 9 & 9,8 & 8,9 & 9,3 & 8,9 \\
\hline Egyetem & 1 & 1 & 2 & 2,4 & 1,8 & 2,1 & 1,8 \\
\hline Végösszeg & 41 & 56 & 97 & 100,0 & 100,0 & 100,0 & 100,0 \\
\hline
\end{tabular}

Forrás: Kérdöívek.

A kijárók csoportjában végzettség tekintetében nincs igazán kiemelkedő végzettségi szegmens, talán leginkább a legális munkavállalók között a szakmunkások 
Hardi Tamás: Határon átnyúló ingázás, munkavállalás az osztrák-magyar határtérségben.

Tér és Társadalom, 19. 2005. 2. 65-81. p.

TÉT XIX. évf. 2005 - 2

részesedése magasabb szembetünően, miközben a gimnáziumot végzettek alulreprezentáltak az ingázók között. Természetesen a végzettség még nem jelenti azt, hogy a munkavállaló a végzettségének megfelelö állást kapott. (Erre vonatkozóan lásd később, a munkavállalók körében végzett külön felmérés eredményeit.)

\section{A munkavállalók körében végzett kérdöives felmérés}

A lakossági felmérésen túl egy külön kérdőívvel kerestünk meg 2004 novemberében olyan személyeket, 500 föt, akik jelenleg is vállalnak munkát Ausztriában. Ilyen formában nem törekedhettünk arra, hogy a kérdöív reprezentatív legyen, hiszen nem ismerjük az alapsokaság jellemzőit sem. Így állításaink elsösorban válaszadóink csoportjára igazak, azonban a viszonylag nagy elemszám miatt már vonhatunk le általános következtetéseket az ausztriai munkavállalókról, illetve munkavállalásról.

\section{Engedéllyel és engedély nélkül munkát vállalók megoszlása}

Az osztrák határ mentén az engedély nélkül munkát vállalók számát nehéz megbecsülni. Korábbi felméréseink, közelítö becsléseink 10 ezer fô fölé tették azok számát, akik (főleg mezőgazdasági idénymunkák idején) naponta átjártak a szomszédba dolgozni. Ebböl a létszámból mintegy 60-70\%-ra becsültük azokat, akik engedély nélkül végezték a kinti munkájukat.

\section{TÁBLÁZAT}

A legális és illegális munkavállalók megoszlása megyénként (Distribution of the Illegal and Legal Employees by Counties)

\begin{tabular}{lccc}
\hline \multirow{2}{*}{ Megye } & \multicolumn{3}{c}{ Az Ausztriába átjáró munkavállalók } \\
\cline { 2 - 4 } & \multirow{2}{*}{ Száma összesen } & \multicolumn{2}{c}{ Ebböl } \\
\cline { 2 - 4 } & & Illegálisan & Legálisan \\
\cline { 2 - 4 } & 130 & 40,8 & 59,2 \\
\hline Györ-Moson- & 273 & 55,3 & 44,7 \\
Sopron & 97 & 66,0 & 34,0 \\
Vas & 500 & 53,6 & 46,4 \\
Zala & & & \\
\hline Végösszeg & & & \\
\hline
\end{tabular}

Forrás: Kérdőívek 2004.

Jelen felmérésben az Ausztriában munkát vállalók csoportját vizsgáltuk, véletlenszerủ mintavétellel. A megkérdezett 500 munkavállaló közül 46,4\% (225fö) engedéllyel, míg 53,6\% (275fö) engedély nélkül járt át Ausztriába dolgozni (felhívnánk a figyelmet, hogy ez az arány nagyon hasonló a reprezentatív lakossági kérdöívünkben tapasztalthoz). Jellemző a megyék közötti eltérés. A legálisan dolgozók aránya Györ-Moson-Sopron megyében a legmagasabb (4. táblázat), talán azért is, 
Hardi Tamás: Határon átnyúló ingázás, munkavállalás az osztrák-magyar határtérségben. Tér és Társadalom, 19. 2005. 2. 65-81. p.

TÉT XIX. évf. 2005 घ 2

Határon átnyúló ingázás ...

73

mert az ingázó keretegyezmény alapján ez a megye kapta a legtöbb ingázó helyet. Korábbi becsléseink tehát többé-kevésbé helyesnek bizonyultak, ami a kijáró munkavállalók megoszlását illeti. Nyilván, az engedéllyel nem rendelkezők aránya nagyobb a mezőgazdasági idénymunkák idején (felmérésünk október végén, november elején zajlott, tehát már az idénymunkák végén).

Az engedéllyel és engedély nélkül munkát vállalók csoportja között alapvető különbség található a munkavállalás jellegét illetően. Úgy tủnik, mind a két csoport stabil, nincs jelentős átjárás közöttük:

- Az illegális munkavállalók közül csak 10 fönek volt korábban engedélye, közülük 4 fönek 1 évig, 5 fönek 2 évig, míg egy fönek 5 évig. 56 fö jelezte, hogy szeretné megszerezni az engedélyt. 2 fö engedélye folyamatban van, ketten valamiért nem kaphattak. Egy fö a munkáltató ösztönzésére nem váltott engedélyt. Kettő időközben itthon talált munkát, s csak alkalomszerủen jár ki. Egy fö GYES-re ment, s megszünt a munkahelye. A többségnek, 209 fönek nem volt korábban sem munkavállalási engedélye, s nem is tervezi beszerezni azt.

- A legálisan dolgozók mintegy 12,4\%-a járt korábban illegálisan munkavállalóként Ausztriába, átmeneti jelleggel, zömében adminisztratív okokból. A 225 föből csak 28 fő válaszolta, hogy korábban már engedély nélkül járt ki dolgozni, átlagosan 3,5 évig, de jellemző, hogy a legtöbben 1-2 évig jártak ki előtte.

Tehát más és más a beállítottsága a két csoportnak. Ehhez még hozzá számíthatjuk, hogy az engedéllyel rendelkezők átlagosan 69 hónapja, míg az engedély nélküliek 40 hónapja járnak át a határon dolgozni, természetesen eltérỏ rendszerességgel.

A legális munkavállalók elsősorban fỏállásban dolgoznak Ausztriában, míg az alkalmi munkavállalás esetén jellemzőbb az engedély hiánya (1. ábra).

\section{1. ÁBRA}

A munkavállalás jellege a legális és illegális munkavállalók körében (The type of Employment by Legal and Illegal Workers)

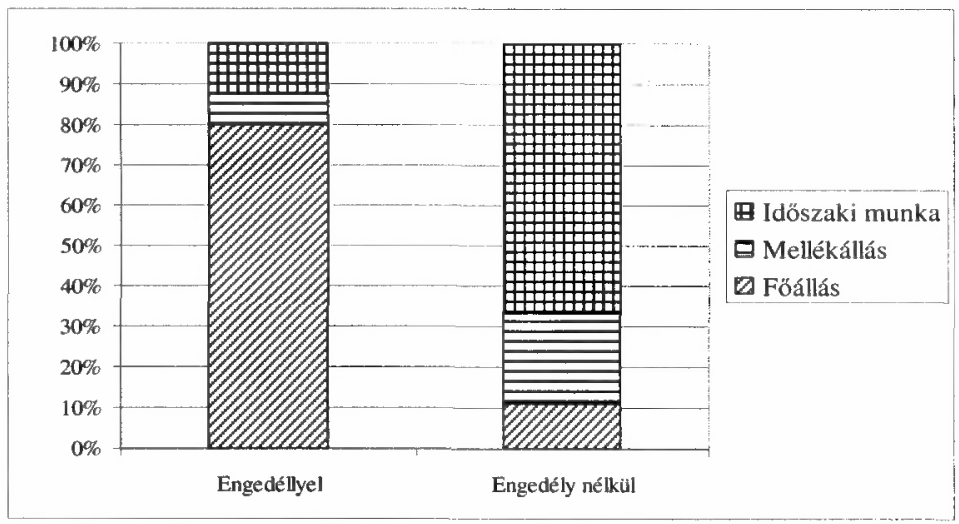

Forrás: Kérdőívek 2004.

Az ábrából jól látható, hogy az engedély nélkül munkát vállalók elsősorban másodállást vagy alkalmi munkát vállalnak Ausztriában. Az engedély nélkül fỏállásban 
Hardi Tamás: Határon átnyúló ingázás, munkavállalás az osztrák-magyar határtérségben.

Tér és Társadalom, 19. 2005. 2. 65-81. p.

$74 \quad$ Hardi Tamás

TÉT XIX. évf. 2005 a 2

dolgozók aránya alig haladja meg a 10\%-ot, s köztük is általában olyanokkal találkozunk, akik adminisztratív okok miatt nem jutottak átmenetileg engedélyhez. Ezzel szemben az engedéllyel rendelkezők $80 \%$-a fóállást vállal Ausztriában.

A legális munkavállalás melletti döntést elsősorban az elérhetö biztonsággal, a hosszabb távon gondolkodással, vagy pedig a környezet ráhatásával: munkaadó, ellenőrzés stb. magyarázták. Anyagi indok egy helyen szerepelt, aki a TB és egyéb anyagi juttatások miatt választotta az engedély kiváltását.

$\mathrm{Az}$ engedély nélkül munkát vállalók az alábbi tevékenységeket nevezték meg, amelyben általában dolgoznak:

- Mezőgazdaság

- Háztartási alkalmazottak

- Faipar

- Illetve más ágazatokban, az alacsonyabban kvalifikált munkakörökben.

Összefüggést találtunk a munkakör kvalifikációs szintje és az engedély megszerzése között. A képzett, megbízható munkavállalót kívánó állások esetében (legyen szakmunka vagy vezetöi munka) a munkavállaló és a munkaadó érdeke is a foglalkoztatás legalizálása, hiszen hosszabb távon gondolkodnak, s a törvények is inkább megengedik a külföldi alkalmazását (könnyebben bizonyítható, hogy nincs rá vállalkozó, hazai munkavállaló). Ezzel szemben a kevésbé kvalifikált, alkalmi munka esetében az engedély megszerzése fölösleges teher mindkét fél számára. Ilyen esetekben elöfordul, hogy a munkaadó ösztönzi a munkavállalót arra, hogy engedély nélkül dolgozzon, söt ez akár az alkalmazás feltétele is lehet. Igaz, kevés ilyen esetröl számoltak be válaszadóink ( 8 eset), de látensen, vélhető, hogy ennél nagyobb az arány.

\section{2. ÁBRA}

Képesítésének megfelelö munkakörben dolgozik-e?

(Do the Responsives Work in Their Scope of Activities?)

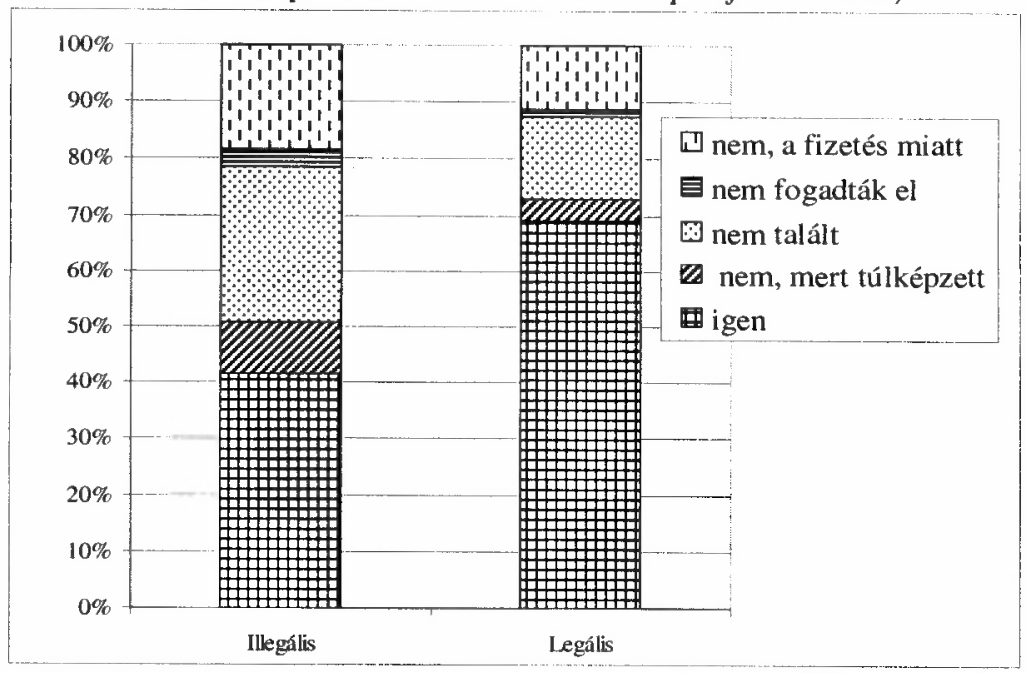

Forrás: Kérdőívek 2004. 
Hardi Tamás: Határon átnyúló ingázás, munkavállalás az osztrák-magyar határtérségben. Tér és Társadalom, 19. 2005. 2. 65-81. p.

TÉT XIX. évf. 2005 — 2

Határon átnyúló ingázás ...

75

A kvalifikáció és az illegális munkavállalás összefüggésére utal az is, hogy míg az engedély nélkül dolgozók $41 \%$-a helyezkedett el a képesítésének megfelelö munkakörben, addig a legális munkavállalók 69\%-a (2. ábra). Általában a főállásban kint dolgozók találnak szakmájuknak megfelelő munkahelyet.

\section{Motivációk}

A külföldi munkavállalás, még ha az néhány kilométeres távolságban is történik, mindenképpen nagyobb áldozatot kíván a munkavállalótól, mintha otthon helyezkedne el (Vári 2002). A küllföldi állampolgár mindenképpen kiszolgáltatottabb, mint a hazai, jobban sakkban tartható. Igaz ez akkor is, ha kicsi a jövedelmi különbség, s különösen így van, ha az otthonihoz képest lényegesen magasabb fizetést ér el a dolgozó. Az - általában, de nem mindig alacsonyabb - munkabér mellett ez az egyik fontos oka a külföldi munkaerö alkalmazásának. Mi motiválja tehát a magyarokat az ausztriai munkavállalásra? Megkértük válaszadóinkat, hogy egy 1-töl 4-ig terjedő skálán értékeljék a különböző motivációkat, ahol az 1-es érték jelentése: egyáltalán nem játszott szerepet, a 4-es érték jelentése: nagyon jelentős szerepet játszott. Ábránkban a válaszok átlagait mutatjuk be, külön bontva az engedéllyel rendelkező és engedély nélkül munkát vállalók válaszait (3. ábra).

\section{3. ÁBRA}

A munkavállalás motivációi

(The Motivations of Employees)

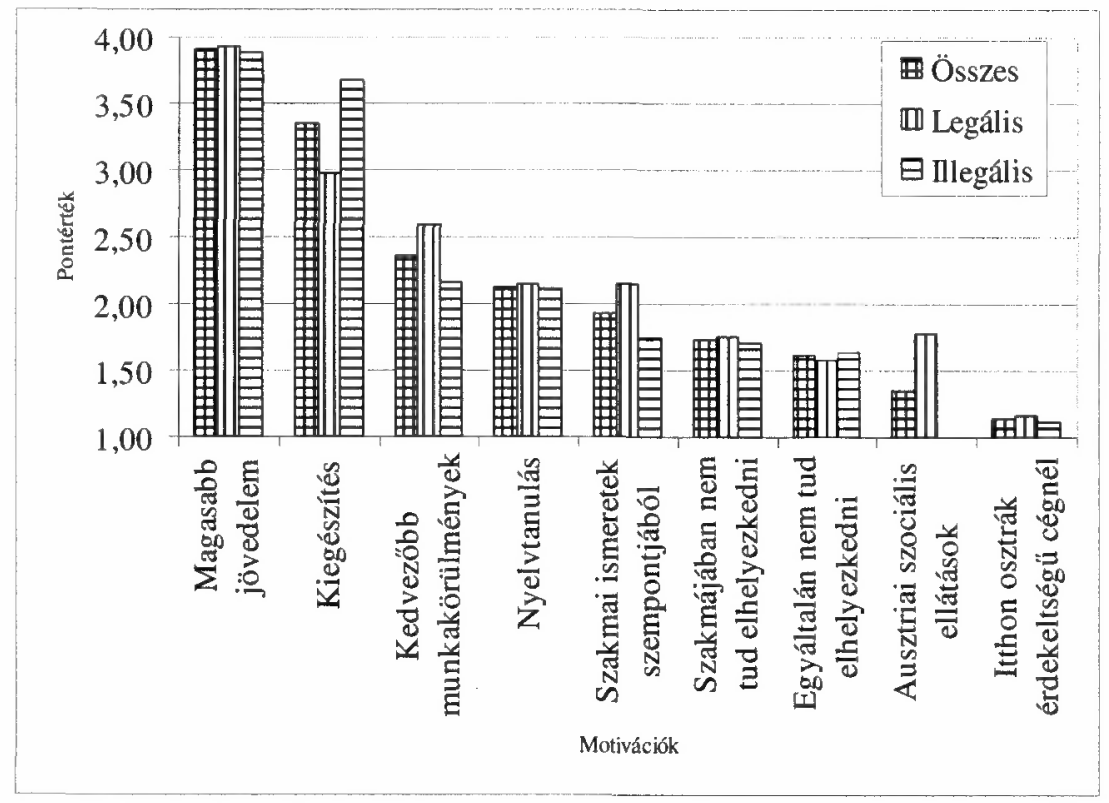

Forrás: Kérdőívek 2004. 
Hardi Tamás: Határon átnyúló ingázás, munkavállalás az osztrák-magyar határtérségben.

Mindkét csoportnál a legfontosabb motiváció a magasabb jövedelem, mint az várható is volt. Megkértük válaszadóinkat, hogy ellenörzésképpen jelöljék be azt a motivációt, amely valamennyi közül a legfontosabb (4. ábra). Itt már egyértelmủen az anyagiak kerültek elsöprő többségbe, mindkét csoport tagjai $90 \%$ felett jelölték meg a „magasabb jövedelem” vagy a „kiegészítö jövedelem” kategóriát. Tehát látható, hogy a munkavállalás jellegének megfelelően a jövedelem vagy a kiegészítő jövedelem a legfontosabb motiváló tényező az ausztriai ingázásban. Munkavállalás esetén nyilván ez a legfontosabb szempont mindenhol. Így igazából a többi válasszal kell érdemben foglalkoznunk. A többi válaszból kitünik, hogy az anyagi motiváció mellett megjelennek más ösztönzök is, elsösorban a legális munkavállalók csoportjában. Ök azok, akik számára jelentösséggel bírtak a hazainál jobb munkakörülmények, a szakmai szempontok, szakmai fejlödés lehetösége (hiszen ök tudnak elsősorban szakmájukban elhelyezkedni), s mindezeknél kisebb mértékben ugyan, de megjelenik az osztrák szociális ellátás igénybevételének lehetỏsége is (ezt természetesen engedély nélküli munkavállalók nem vehetik igénybe, így ez a motiváció az esetükben nem értékelhetö). Minthogy a szociális ellátás igénybevételének értékelése 2 alatt marad, azt mondhatjuk, hogy a szempont nem játszik szerepet az ausztriai munkavállalás során.

Ezzel szemben mindkét csoport esetében - szinte azonos mértékben - megjelenik a nyelvtanulás lehetösége ösztönzö erőként. Különösen a fiatalok esetében, akik további karrierjüket is Ausztriában képzelik el.

\section{4. ÁBRA}

A munkavállalás legfontosabb motivációi

(The Most Important Motivations of Employees)

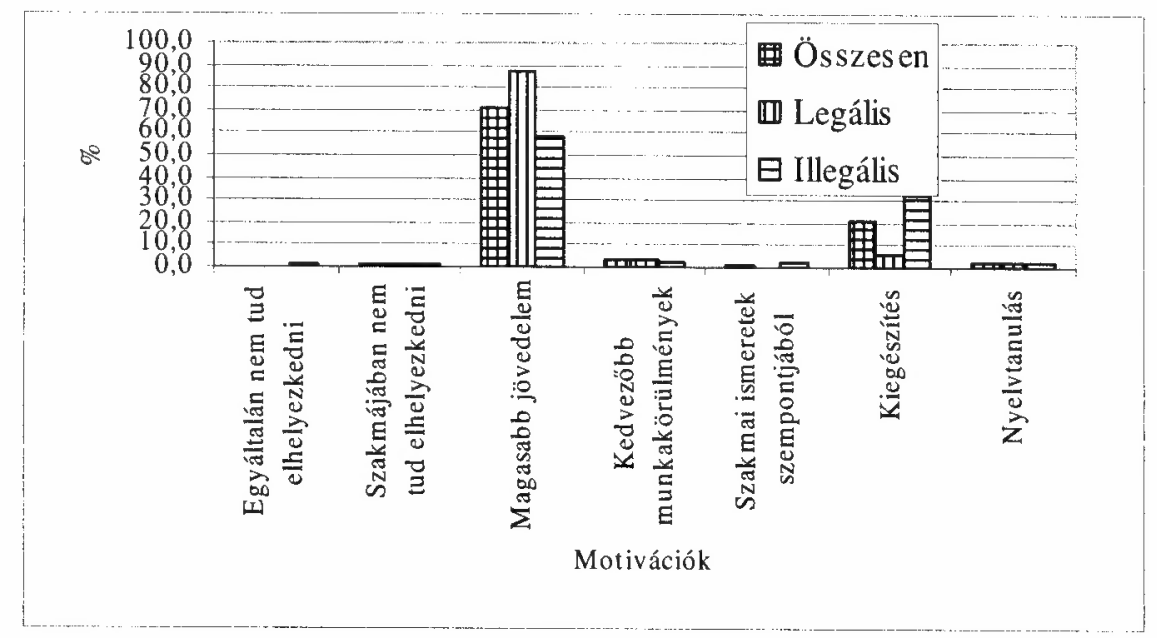

Forrás: Kérdőívek 2004.

Érdekes ugyanakkor, hogy a hazai elhelyezkedés nehézsége alig motiválta a két csoport tagjait. Azt mondhatjuk, hogy ez a tényezö nem bír jelentőséggel. Két 
Hardi Tamás: Határon átnyúló ingázás, munkavállalás az osztrák-magyar határtérségben. Tér és Társadalom, 19. 2005. 2. 65-81. p.

TÉT XIX. évf. 2005 业 2

Határon átnyúló ingázás...

77

módon is rákérdeztünk erre, egyrészt a szakmai elhelyezkedés lehetőségére, másrészt az általános munkalehetőségek vonatkozásában. Eredményként tehát azt kaptuk, hogy az Ausztriában munkát vállaló honfitársaink itthon is el tudnának helyezkedni, zömében szakmájukban.

Megállapítható tehát, hogy az ingázók többségére itthon is van munkaerỏ-piaci kereslet, ők elsősorban a magasabb bérek, másodsorban a munkahelyi körülmények és a karrierlehetöségek miatt helyezkednek el a szomszéd ország munkaadóinál. Így nem csoda, ha egyes szakmákban a magyar oldalon szakemberhiány alakul ki.

\section{Az ausztriai munkahely megtalálása}

A határon átnyúló információáramlás az egyik akadálya vagy segítője lehet a munkavállalásnak. Kérdöivünkben megvizsgáltuk, hogy a megkérdezettek jelenlegi munkahelyükre milyen információforrás segítségével akadtak rá. Zárt kérdésünkben tơbbféle hivatalos és informális lehetőség közül választhatott a munkavállaló (5. ábra).

\section{5. ÁBRA}

Hogyan találta meg a munkavállaló ausztriai munkahelyét?

(How Did the Employee Find the Work Place in Austria?)

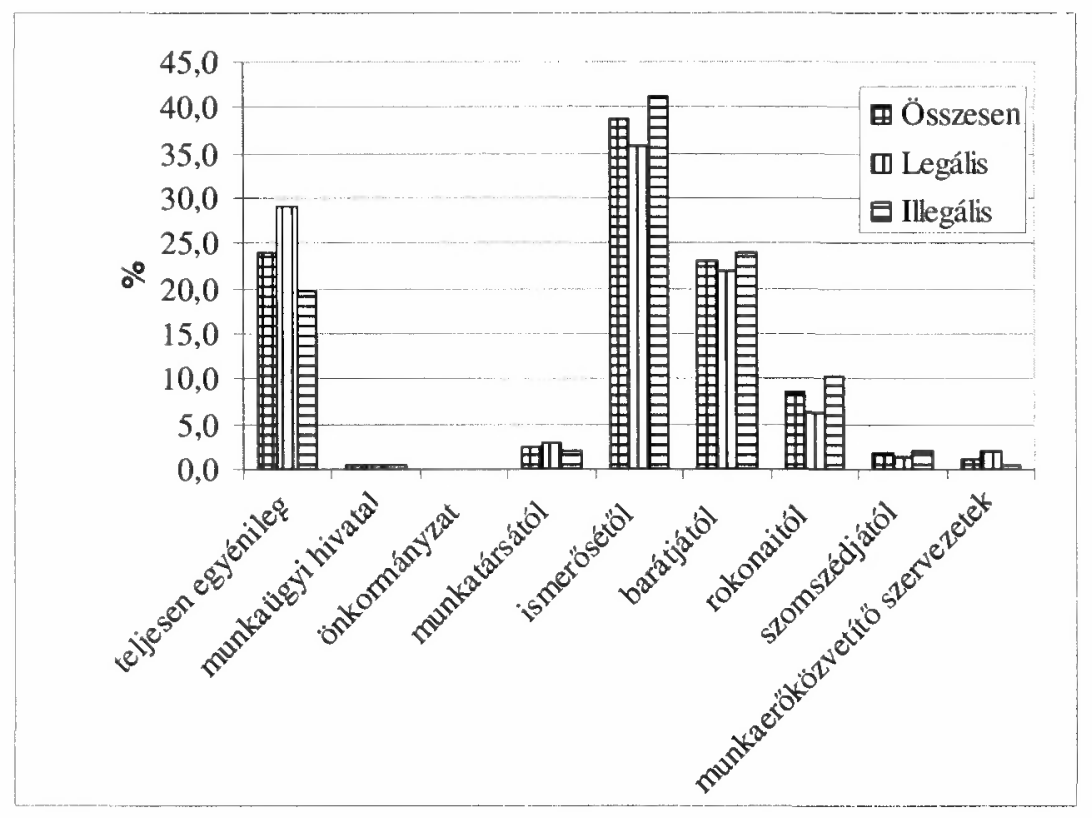

Forrás: Kérdőívek 2004.

A válaszokból kitünik, hogy az ausztriai munkalehetőségek megtalálása során az egyéni munkakeresés és a baráti, rokoni ismeretségi kör információi dominálnak.

Az engedéllyel rendelkezők csoportjában is az ismeretség az elsődleges információforrás, de ott jelentős arányt képviselnek azok is, akik egyénileg jutottak el mai 
Hardi Tamás: Határon átnyúló ingázás, munkavállalás az osztrák-magyar határtérségben.

munkaadójukhoz. Ez elsősorban azt jelenti, hogy újsághirdetés vagy egyéb hirdetés útján találta meg a munkahelyet, hasonlóképpen, mint itthon.

$\mathrm{Az}$ engedéllyel nem rendelkezök körében ez az út kevésbé járt, ott elsősorban az ismerősökön keresztül megszerzett információ alapján vállaltak munkát.

Szembetünő ugyanakkor, hogy elenyésző azok száma, akik hivatalos szerveken, munkaügyi hivatalon vagy önkormányzaton keresztül jutottak ausztriai munkahelyhez. Ez nyilvánvalóan következik abból a korábban megismert tényböl, hogy Burgenlandban nem a hazai munkanélküliek dolgoznak, hanem olyanok, akik hazai állásukat adták fel, vagy másodállásként ingáznak át a határon. Így ök munkahelyváltásuk során nem kerülnek kapcsolatba a hivatalokkal, vagy csak abban a fázisban, amikor az adminisztratív ügyeiket kell intézni, tehát a munkakeresés fázisában nem.

\section{Nehézségek, diszkrimináció}

A munkavállalás nehézségeivel kapcsolatban először arról érdeklödtünk, hogy válaszadóink tapasztaltak-e valamilyen pozitív vagy negatív diszkriminációt munkahelyükön (6. ábra).

Lényegében viszonylag kevesen említettek ilyen esetet. Pozitív diszkriminációt a válaszadók 8,4\%-a említett, elsösorban arra hivatkozva, hogy „,szeretik a magyarokat”, megbecsülik öket, mert szorgalmas, jó munkaerỏnek tartják.

\section{6. ÁBRA}

A pozitiv és negativ diszkrimináció

(Positive and Negative Discrimination)

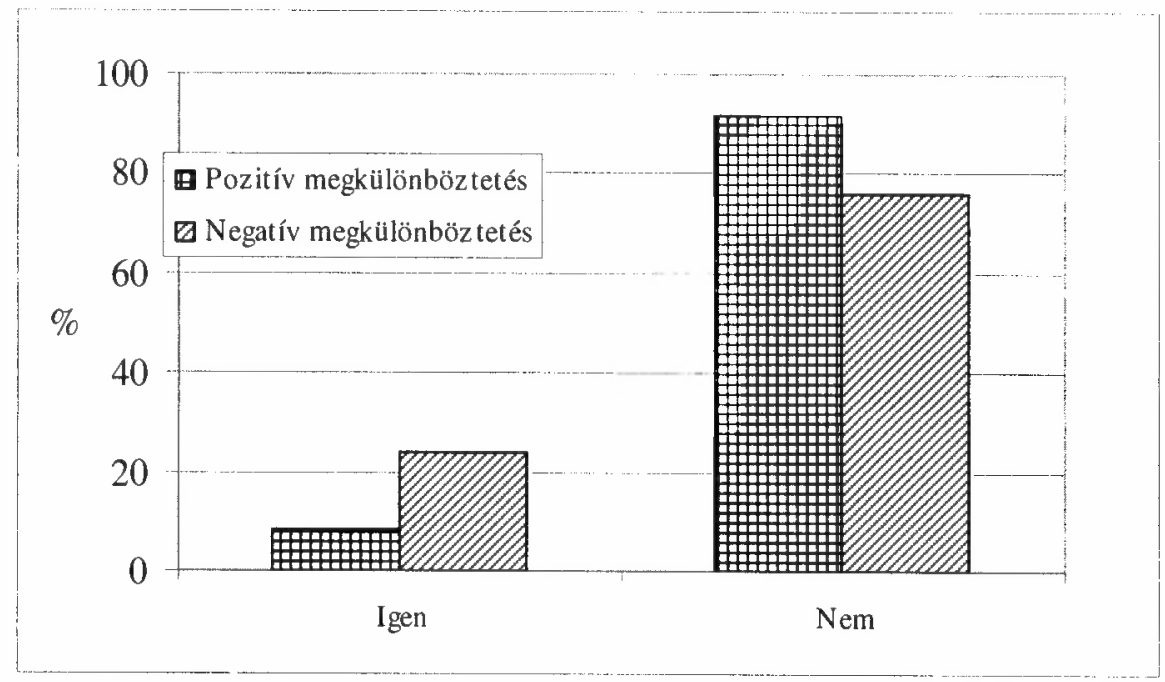

Forrás: Kérdōívek 2004.

Negatív diszkriminációra viszont már a válaszadók közel negyede (24\%) panaszkodott, s érdekes módon a legálisan alkalmazottak valamivel nagyobb arányban. A 
Hardi Tamás: Határon átnyúló ingázás, munkavállalás az osztrák-magyar határtérségben. Tér és Társadalom, 19. 2005. 2. 65-81. p.

negatív megkülönböztetéssel kapcsolatban két jellemzö típust különíthetünk el: „,a rosszabb és több munka, kevesebb bérért" válaszok a külföldi munkavállalók általános problémáját tükrözik. Másrészt a leggyakoribb válasz szerint az osztrákok „lenézik a magyarokat”. Ez a sztereotip válasz már gyakran, más kontextusban is felmerült (Hardi 1999).

A többség azonban arról számolt be, hogy nem tapasztalt sem pozitív, sem negatív megkülönböztetést ausztriai munkája során.

A nehézségek vizsgálatakor azonban előtünt újra a negatív diszkrimináció, amit ekkor a második legfontosabb problémaként említettek, a 97 föböl 56-an (7. ábra). Ez a negatív megkülönböztetés vélhetöen a nyelvtudás elégtelenségéből és az eltérő szokásokból keletkezik, hiszen ez a két tényező még nagyon fontos a nehézségek között. A legnagyobb problémát (66 válasz) a nyelvtudás jelenti, az eltérỏ szokások csak harmadik a sorban. A munkakultúra eltérései ennél már jóval kisebb gondot okoznak a munkavállalóknak. Ugyanakkor a viszonylag kis távolság, s így a jól informáltság miatt lényegesen kevésbé problematikus a jogi keretekbe, a mindennapi életbe való beilleszkedés, $s$ a külföldi munkavállalás nem okoz jelentős családi problémát itthon, hiszen a munkavállalók jelentős része napi ingázó, tehát a család szempontjából nem jelent nagy különbséget, hogy a családtag itthon vagy külföldön vállal-e munkát.

\section{7. ÁBRA}

A munkavállalás nehézségei

(Difficulties of Employement)

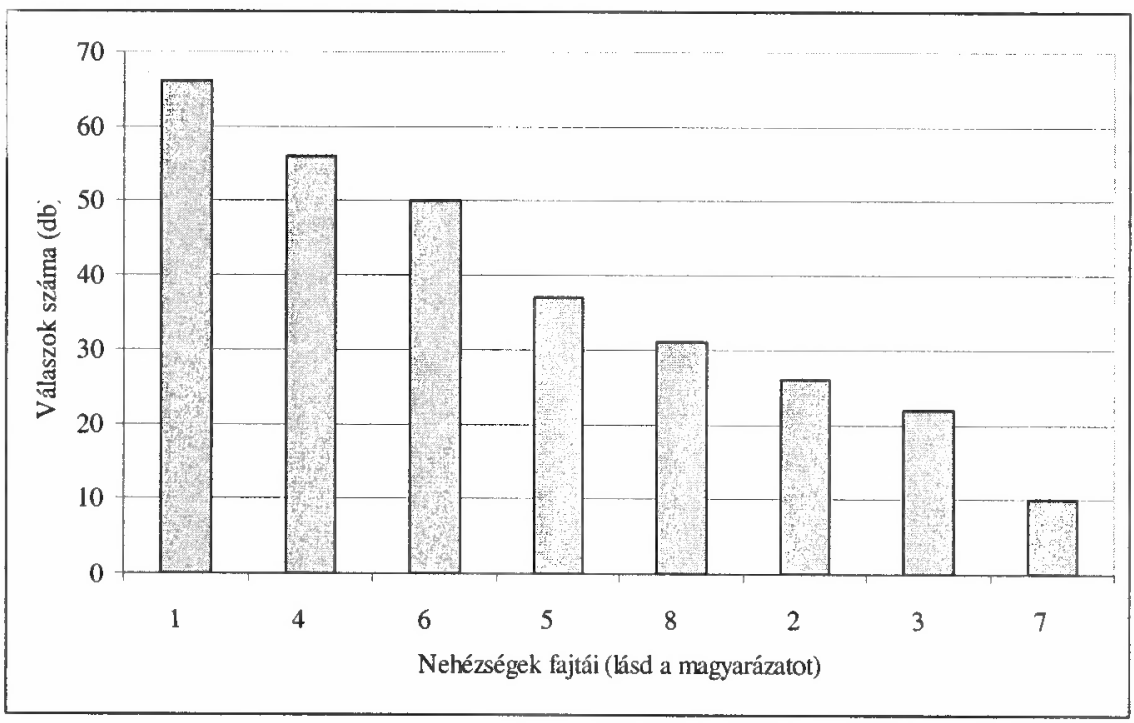

A nehézségek fajtái: $1=$ nyelvi nehézségek; $2=$ jogi nehézségek (pl. nincs tisztában az ausztriai jogi környezettel, munkavállalói jog); $3=$ külfớldi munkavállalóként a beilleszkedés nehézsége; 4=negatív diszkrimináció; $5=$ magyartól eltérỏ munkakultúra, munkahelyi szokások (pl. fegyelem, lojalitás); $6=$ általában a magyartól eltéró szokások, gondolkodásmód; 7 = családi kapcsolatai sérültek/sérülnek a távolléte miatt; 8= utazási nehézségek (állandó lakhely és a munkahely között).

Forras: Kérdőivek 2004. 
Hardi Tamás: Határon átnyúló ingázás, munkavállalás az osztrák-magyar határtérségben.

\section{Összegzés}

Vizsgálatunk két kérdőív eredményének elözetes, s korántsem teljes kiértékelése. Az osztrák-magyar határ mentén élők ausztriai munkavállalási szokásainak általános jellemzőire kívántunk rávilágítani. További elemzésekkel, összehasonlításokkal mélyebben megismerhetjük ezt a világot, de elöljáróban az alábbi következtetéseket vonhatjuk le:

- Az ingázás a Nyugat-dunántúli régió lakosai közủl elsősorban a határ közvetlen közelségében élőket érinti, akik már a rendszerváltás utáni időszakban ki tudták használni ezt a lehetőséget.

- Az egész régióból mintegy 60-70 ezer főre tehetjük azok számát, akik valaha már dolgoztak Ausztriában. Tapasztalható, hogy jelenleg a szükebb sáv népességéből kerülnek ki az ingázók, számuk 7-8 ezer fö közé tehetô. Nyilván idénymunkák idején ez a szám lényegesen nagyobb is lehet, s ilyenkor a mérleg jobban elbillen az illegális szféra javára.

- Több forrásból is megerősíthetjük, hogy az illegális munkavállalók száma valamivel meghaladja az engedéllyel rendelkezőkét, de semmi esetre sem igazolhatóak bizonyos korábbi osztrák vélemények arról, hogy akár az EUcsatlakozás előtt, akár az után a jelenség robbanásszerủen változott volna.

- Az engedéllyel és engedély nélkül dolgozók csoportja stabil, kicsi az átjárás közöttük, engedély nélkül inkább csak az alkalmi fizetés-kiegészítést keresők lépik át a határt, $\mathrm{s}$ ebben a körben jellemző az alacsonyabban kvalifikált munkaerö alkalmazása.

- Egyértelmú az anyagi motiváció, elsősorban a magasabb bérért ingáznak a munkavállalók Ausztriába. Az ingázók csoportja nagy valószínúséggel itthon is el tudna helyezkedni, hiszen sok divatos ingázó szakmában hiány is mutatkozik.

- Kvalifikált munkaeró esetén mind a munkavállaló, mind a munkaadó a legalitásra törekszik, hosszú távon, kiszámítható módon kívánja foglalkoztatni alkalmazottját.

- A munkavállalás nehézségeit elsösorban a nyelvtudás hiánya vagy rossz minősége, s a kulturális ellentétek jelentik. Ezek leküzdése csak képzéssel, tanulással, megismeréssel lehetséges.

Valószínủsíthető, hogy szabad munkaerő-áramlás bevezetésével a munkavállalás módja egyre inkább a legális szférába fog átcsúszni. Az illegális foglalkoztatás mindig is megmarad, de nem elsősorban a külföldiek vonatkozásában, hanem a gazdaság általános jelenségeként. A hazai bérek és munkakörülmények javulásával várható, hogy a határtérségböl ingázók száma növekedni fog ugyan, de nem látványos mértékben. A jelenleg támasztott nehézségek miatt nem gondolnánk, hogy lényegesen megnỏne a kijárók száma, sőt azt tapasztaljuk a kapott válaszokból, hogy az ingázás egyre inkább a határ közelében élők életének részévé válik. 
Hardi Tamás: Határon átnyúló ingázás, munkavállalás az osztrák-magyar határtérségben. Tér és Társadalom, 19. 2005. 2. 65-81. p.

Összességében azt mondhatjuk, hogy a munkavállalás lehetősége az, ami leginkább hat az integrált határrégió kialakulására a térségben. Egy közepes városnyi ember szerzett már ennek révén tapasztalatot a határ másik oldalán élőkröl, $s$ arról a világról, s kialakult már az a kör, amely engedéllyel vagy engedély nélkül, de „hazajár” Ausztriába dolgozni. A határ munkaügyi elválasztó szerepének csökkenésével azt várhatjuk, hogy ez a szféra egyre inkább egységes lesz, s kialakul az az átmeneti zóna a határ mentén, amely a Kárpát-medencének ezt a táját mindig is jellemezte.

\section{Irodalom}

Csapó T. (1999) Határ menti egyưttmủködések a munkaerőpiac területén, különös tekintettel Vas és Zala megyére. - Nárai M.-Rechnitzer J. (szerk.) Elválaszt és összeköt - a határ. Társadalmi-gazdasági valtozások az osztrák-magyar határ menti térségben. MTA RKK. Pécs-Gyỏr. 269-295. o.

Csizmadia Z. (2005) Határ menti társadalmi kapcsolatok a Nyugat-dunántúli régióban. - Tér és Társadalom. 2. 47-63. o.

Hardi T. (1999) A határ és az ember - Az osztrák-magyar határ mentén élỏk képe a határról és a „másik oldalról", - Nárai M. - Rechnitzer J. (szerk.) Elválaszt és összeköt-a határ. MTA RKK, Györ-Pécs. 159-189. o.

Hardi T. (2004) Az államhatáron átnyúló régiók formálódása. - Magyar Tudomány. 9. 991-1001. o.

Nárai M. (1999) A határ mente mint élettér. - Nárai M.-Rechnitzer J. (szerk.) Elválasżt és összeköt a határ. Györ-Pécs, MTA RKK. 129-158. o.

Nyugat-Magyarország és Kelet-Ausztria közös munkaerőpiac-politikai stratégiája. (1998) Reginnov Tanácsadó Kft., Vasvár.

Rechnitzer J. (1999) Az osztrák-magyar határ menti együttmúködés a kilencvenes években. - Nárai M.Rechnitzer J. (szerk.) Elvalaszt és összeköt-a határ. MTA RKK, Győr-Pécs. 73-127. o.

Rechnitzer J. (2005) Az osztrák-magyar határ menti együttmúkỏdés múltja, jelene. - Tér és Társadalom. 2. 7-29. 0 .

Sallai J. (2003) Az osztrák-magyar határ kijelölése utáni problémák rendezése. - Tér és Társadalom. 4. 157-171. o.

Vári A. (2002) A határon átnyúló munkavállalás jelentősége és problémái az Esztergom-párkányi régió példáján. - Kovács N.-Szarka L. (szerk.) Tér és terep. Tanulmányok az etnicitás és az identitás kérdéskörébôl. Az MTA Kisebbségkutató Intézetének Évkönyvei 1. Akadémiai Kiadó, Budapest. 219-240. o.

\section{TRANSBORDER COMMUTING, EMPLOYMENT ON THE AUSTRIAN-HUNGARIAN BORDER REGION}

\section{TAMÁS HARDI}

To enter employement for a much better payment is a great opportunity for people living next to the Austrian - Hungarian border. For this they do not even have to move, but they can commute every day. Besides, period employement can be a good extra payement for the ones who work in Hungary. This study shows by interviews the development of transborder work - cooperations set up after the Hungarian system - change. The study shows the groups of legal and illegal employees, appraises the number, describes the characteristics, motivation and difficulties of Hungarians working in Austria by the help of public-, and special employee questionnaires. 